\title{
DStruBTarget: Integrating Binding Affinity with structure similarity for ligand binding protein prediction
}

\section{Cong Fan ${ }^{1,2}$, Ping-pui Wong ${ }^{1,2}$, Huiying Zhao ${ }^{1,2^{*}}$}

${ }^{1}$ Guangdong Provincial Key Laboratory of Malignant Tumor Epigenetics and Gene Regulation, Sun Yat-sen Memorial Hospital, Sun Yat-sen University, Guangzhou, Guangdong Province, China, 510220. 2 Department of Anesthesiology, Sun Yat-sen Memorial Hospital, Sun Yat-sen University, Guangzhou,
Guangdong Province, China, 510220.

*To whom correspondence should be addressed: zhaohy8@mail.sysu.edu.cn

Table S1. The names and functions of the correctly predicted proteins binding with query drugs by DstruBTarget

\begin{tabular}{|c|c|c|c|c|}
\hline Uniprot ID & name & Family & function & $\begin{array}{l}\text { Pathway/bio- } \\
\text { process }\end{array}$ \\
\hline P41597 & $\begin{array}{l}\mathrm{C}-\mathrm{C} \text { chemokine } \\
\text { receptor type } 2\end{array}$ & $\begin{array}{l}\text { G-protein } \\
\text { coupled } \\
\text { receptor } 1\end{array}$ & $\begin{array}{l}\text { 1. Regulates the } \\
\text { expression of T- } \\
\text { cell inflammatory } \\
\text { cytokines and T- } \\
\text { cell differentiation, } \\
\text { promoting the } \\
\text { differentiation of } \\
\text { T-cells into T- } \\
\text { helper } 17 \text { cells } \\
\text { (Th17) during } \\
\text { inflammation (By } \\
\text { similarity) }\end{array}$ & $\begin{array}{l}\text { 1. Chemokine- } \\
\text { mediated } \\
\text { signaling } \\
\text { 2. Cytokine- } \\
\text { mediated } \\
\text { signaling } \\
\text { 3. G protein- } \\
\text { coupled receptor } \\
\text { signaling } \\
\text { 4. Receptor } \\
\text { signaling pathway } \\
\text { via JAK-STAT }\end{array}$ \\
\hline \multirow[t]{2}{*}{ P42336 } & \multirow[t]{2}{*}{$\begin{array}{l}\text { Phosphatidylinositol } \\
\text { 4,5-bisphosphate 3- } \\
\text { kinase catalytic } \\
\text { subunit alpha } \\
\text { isoform }\end{array}$} & \multirow[t]{2}{*}{$\begin{array}{l}\text { PI3/PI4- } \\
\text { kinase } \\
\text { family }\end{array}$} & $\begin{array}{l}\text { 1. Involved in the } \\
\text { generation of } \\
\text { PTP3 which } \\
\text { activates signaling } \\
\text { cascades involved } \\
\text { in cell growth, } \\
\text { survival, } \\
\text { proliferation, } \\
\text { motility and } \\
\text { morphology }\end{array}$ & $\begin{array}{l}\text { 1. PDPK1-AKT1 } \\
\text { pathway } \\
\text { 2. PDK1 and } \\
\text { protein kinase C } \\
\text { pathway } \\
\text { 3. Cytokine- } \\
\text { mediated } \\
\text { signaling }\end{array}$ \\
\hline & & & $\begin{array}{l}\text { 2. Essential in } \\
\text { endothelial cell } \\
\text { migration during } \\
\text { vascular } \\
\text { development }\end{array}$ & $\begin{array}{l}\text { 4. Epidermal } \\
\text { growth factor } \\
\text { receptor signaling } \\
\text { 5. ERBB2 } \\
\text { signaling }\end{array}$ \\
\hline
\end{tabular}


through VEGFA

signaling

3. Required for lymphatic

vasculature

development

4. Participates in cardiomyogenesis in embryonic stem cells

\section{G-protein coupled} CX3C che
receptor 1

\section{Q13535}

Q16418
Integrin beta- 2 subfamily mitosis and receptor 1

PI3/PI4-

kinase

family.

ATM

1. Binds to CX3CL1 and mediates both its adhesive and migratory functions

2. Acts as coreceptor with CD4 for HIV-1 virus envelope protein

1. DNA damage sensor, activates checkpoint signaling upon genotoxic stresses

2. Involves in inhibition of DNA replication and promote DNA repair, recombination and apoptosis

Integrin
beta chain

1. Contributes to natural killer cell cytotoxicity

2. Involved in leukocyte adhesion and transmigration of leukocytes
6. Fc-epsilon receptor signaling

7. G proteincoupled receptor signaling

8. Insulin receptor signaling pathway

9. T cell receptor signaling

10. Vascular endothelial growth factor receptor signaling

1. G proteincoupled receptor signaling

2. Negative regulation of apoptotic signaling

3. Phospholipase C-activating $\mathrm{G}$ protein-coupled receptor signaling
1. Cytokine-
mediated
signaling
2. Integrin-
mediated
signaling 
including T-cells

and neutrophils

3. Triggers

neutrophil

transmigration

during lung injury

4. Contributes to apoptotic

neutrophil

phagocytosis by

macrophages

P22756

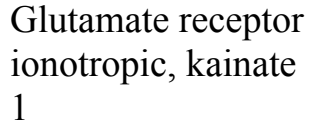

Glutamategated ion channel (TC 1.A.10.1) family. GRIK1 subfamily
3. Toll-like receptor 4 signalin

\section{An excitatory Ionotropic neurotransmitter at glutamate receptor} many synapses in signaling the central nervous system.

2. Binding of the excitatory neurotransmitter L-glutamate and converts the chemical signal to an electrical impulse. 